\title{
GESTÃO COOPERADA E A EFETIVIDADE DO DIREITO INTERNACIONAL AMBIENTAL
}

\section{COOPERATIVE MANAGEMENT AND THE EFFECTIVENESS OF THE INTERNATIONAL ENVIRONMENTAL LAW}

\author{
${ }^{1}$ Fabiana Cristina Teodoro \\ ${ }^{2}$ Camila Cardoso Lima
}

\section{RESUMO}

A necessidade de compatibilização entre utilização e preservação dos recursos naturais tem sido tema relevante em nível internacional. A inquietação frente a determinado estudo se dá em prol da concepção da transformação do conceito de soberania flexível a realidade vivida, de interligação entre os povos e Estados que implica em uma responsabilidade compartilhada e cooperação na garantia da efetivação da proteção ao meio ambiente global. O que se pretende demonstrar neste estudo é a necessidade de avanço neste processo, não só pela sua urgência concreta, mas também para o atendimento aos Objetivos do Desenvolvimento Sustentável - ODS.

Palavras-chave: Direito ambiental, Gestão cooperada, Integração

\begin{abstract}
The need for compatibility between use and preservation of natural resources has been important issue internationally. Restlessness against particular study takes place in favor of flexible sovereignty concept of transformation of the design reality lived, interconnection between peoples and states which implies a shared responsibility and cooperation in ensuring the effective protection of the global environment. What is intended to demonstrate in this study is the need to advance in this process, not only for their actual urgency, but also to meet the objectives of sustainable development - ODS .
\end{abstract}

Keywords: Environmental law, Cooperative management, Integration

\footnotetext{
${ }^{1}$ Mestrando em Direito Negocial pela Universidade Estadual de Londrina - EU, Paraná, PR.(Brasil). Professora Universidade Norte do Paraná - UNOPAR. Paraná, PR. (Brasil) E-mail: fabiana.teodoro@ hotmail.com

${ }^{2}$ Doutoranda em Geografia pela Universidade Estadual de Londrina, UEL, Paraná - PR. (Brasil). Advogada. Email: cclima.cl@gmail.com
} 


\section{INTRODUÇÃO}

O presente artigo se propõe, não exaustivamente, a realizar uma reflexão acerca do clássico conceito de soberania e sua transformação em prol da compatibilidade com a preservação ambiental global, defendendo a ideia de uma flexibilização do atual conceito, essencial para a efetiva garantia do direito humano à um meio ambiente ecologicamente equilibrado, limpo e sadio para toda a comunidade planetária. Tal tema, embora já seja objeto de análise de alguns doutrinadores do direito ambiental e internacional, ainda gera inúmeras divergências, exigindo assim maior atenção, estudo aprofundado e melhor compreensão para que possa se consolidar social, política e juridicamente.

Assim, a pesquisa ora apresentada visa formular um arcabouço científico sólido na defesa da viabilidade de modificação da soberania territorial, sem ofender a autonomia interna dos Estados, mas apresentando a ideia de uma governança global no que se refere à direitos humanos, entre eles, o direito, a um meio ambiente equilibrado, limpo e sadio para toda a espécie humana.

O caráter transfronteiriço das questões ambientais e a crescente percepção de que o consumo exacerbado tem trazido ao planeta situações ambientais alarmantes, suscitou, a partir da metade do século XX, articulações no âmbito internacional no sentido de despertar nos indivíduos a consciência de que a maneira ilimitada de produção não era condizente com a limitada capacidade de recursos naturais.

Os compromissos internacionais já realizados precisam ser levados adiante, e novos compromissos podem ser firmados. A situação de crise ambiental que o Planeta se encontra exige ações concretas globais e locais como o maior desafio a ser enfrentado pela humanidade.

Diante desse contexto a questão que se impõe consiste em que se, diante do individualismo característico da sociedade de consumo é possível uma mudança de olhar acerca da preservação do meio ambiente. Embora muito se tenha avançado no sentido de internalização da preocupação com relação ao meio ambiente nos diversos ordenamentos jurídicos, é fundamental uma mudança nas atitudes preponderantes na sociedade contemporânea no que diz respeito às práticas consumistas.

O desafio consiste em construir um olhar conjunto sobre o meio ambiente em uma sociedade tão marcada pelo individualismo. 
Nessa esteira, é compatível a perpetuação do clássico conceito de soberania dos Estados diante de um mundo cada vez mais globalizado e interligado, e ainda, diante de uma degradação ambiental crescente?

Será viável, jurídica e politicamente, uma transformação de tal conceito, em algo transcendente e includente, a fim de viabilizar a sustentabilidade efetiva do planeta, com a colaboração entre Estados em uma ideia de integração na gestão e proteção dos recursos naturais?

Para tentar responder a tais questionamentos, imperioso se fez uma breve análise acerca da relação entre o processo de globalização, soberania estatal absoluta e preservação ambiental.

Utilizando-se de bibliografia pertinente, pretende-se demonstrar a importância de se conceber a flexibilização do clássico conceito de soberania dentro de um mundo globalizado, sem fronteiras e cada vez mais interligado, como medida indispensável na efetiva garantia à um direito a um meio ambiente sadio e equilibrado, não só no âmbito interno dos Estados, mas para toda a humanidade.

Para tanto será realizada uma breve explanação sobre o processo de globalização e suas consequências no mundo contemporâneo, os impactos que exerce sobre o conceito de soberania territorial e sua relação com a efetividade da proteção jurídica ao meio ambiente, conforme documentos internacionais de compromisso.

BREVE ANÁlise A RESPEITO DA GLOBALIZAÇÃo E O MEIO AMBIENTE:

O último século foi marcado por inúmeros avanços e grandes mudanças no cenário mundial, como nunca antes. Eventos como as duas Grandes Guerras, Revolução Industrial, Guerra Fria e a queda do muro de Berlim, impactaram na história do mundo e se refletiram no universo jurídico, significativamente, no Direito Internacional.

De tais acontecimentos culminaram na positivação de direitos humanos (civis e políticos; sociais, econômicos e culturais), melhorias nas condições de trabalho e o estabelecimento de direitos trabalhistas garantidos, transformação dos modos de produção e consumo, expansão e solidificação do capitalismo em praticamente todo o globo. 
A globalização percebida nos dias de hoje, indubitavelmente tem como pano de fundo todos os eventos acima citados, direta ou mesmo indiretamente. Embora nasça no campo econômico, torna-se o principal desafio social e político do pós Guerra.

A globalização é a palavra-chave de toda a modificação estrutural do sistema econômico mundial, atingindo de maneira substancial o Estado Nacional e sua soberania.

Importante destacar que o conceito de globalização adotado nessa pesquisa, é aquele apresentado por Habermas (2001, p. 78), que o utiliza para se referir "a descrição de um processo, não de um estado final”, ou seja, trata-o como um evento vivo, em constante movimento, modificação e expansão.

O processo de globalização inicia, com maior intensidade no final dos anos 70, uma desnacionalização das instituições baseadas no Estado Nacional. Faz surgir uma sociedade global, como anteriormente mencionado, inaugurada pelo âmbito econômico, mas que se amplia e reflete na comunicação, cultura, consumo e o meio ambiente, objeto desse estudo.

O crescimento demográfico, acompanhado da expansão da renda e de mudanças qualitativas nos hábitos individuais e sociais implicou em um vertiginoso crescimento dos mercados. (ROSSETTI e ANDRADE, 2012, p. 45)

Na sequência, o antigo sistema de produção de inspiração fordista firmado sobre o modelo de enormes plantas industriais nas quais todo o aparato produtivo permanecia imóvel em uma determinada localidade, foi substituído pelo contemporâneo sistema de produção fragmentado e desterritorializado. Este passou a ser composto de uma rede, na qual vários micro processos independentes vão se somando e integrando. Tal processo permite tanto a agregação de componentes elaborados e advindos de vários países como a mobilização do aparato produtivo de um país realocando-o em outro, deste modo o sistema produtivo atual prescinde de uma única nação. (TORRES e MUNIZ, 2014, p.6)

Avanços tecnológicos em diversas áreas possibilitaram uma interconectividade inédita que caracteriza o fenômeno da globalização.

Todos estes elementos foram possíveis graças aos avanços tecnológicos que impulsionaram o fenômeno da globalização, e, com ele uma inédita interconectividade entre os países.

A globalização estende-se, cada vez mais, para além da perspectiva econômica, tornando evidente a inter-relação dos diversos espaços sociais e políticos, após a década de 60 , em especial, às questões que versam sobre o meio ambiente, a exploração de recursos naturais e os limites naturais do planeta. 
O caráter transfronteiriço das questões ambientais e a crescente percepção de que o consumo exacerbado tem trazido ao planeta situações ambientais alarmantes, suscitou, a partir da metade do século XX, articulações no âmbito internacional no sentido de despertar nos indivíduos a consciência de que a maneira ilimitada de produção não era condizente com a limitada capacidade de recursos naturais.

Avanços tecnológicos permitiram estudos com alcance de sofisticação e confiabilidade que contribuíram para uma disseminação da percepção de que o modo de produção contemporâneo e a frenética necessidade de consumir corroborarão para um futuro planetário nada animador.

Voltada para os interesses imediatos, indiferente às consequências a longo prazo, a frenética perseguição da produção e das satisfações materiais é denunciada, cada dia um pouco mais, como provocadora da poluição do meio ambiente, da erosão da biodiversidade e do aquecimento climático. No ritmo atual de crescimento, em um século todos os recursos em combustíveis fósseis estarão esgotados. As degradações do meio ambiente são tais que a capacidade dos ecossistemas de responder às demandas das gerações futuras não pode mais ser considerada segura. (LIPOVETSKY, 2007, p.340)

Com efeito, problemas como a extinção de espécies, destruição da camada de ozônio, aquecimento global, estresse hídrico, são algumas das constatações das ciências que vêm chamando a atenção da sociedade global e despertando preocupações.

Entretanto, como bem mencionado por Pinheiro e Bassoli (2005, p. 109), “a globalização econômica expressa a confirmação das transformações alcançadas pelo mundo contemporâneo e que, se proporcionou avanços tecnológicos, o mesmo não aconteceu no plano social, ambiental e político".

Adotamos ao longo do século XX, um modelo insustentável de vida. O modo de produção capitalista que se consolidou pós Revolução Industrial, influenciou culturas e sociedades, fazendo surgir "um novo modelo econômico globalizante". (PINHEIRO; BASSOLI, p. 110)

Não obstante, é preciso repensar a relação com o planeta que nos hospeda, uma vez que os impactos ambientais deixam óbvio já não ser possível continuar replicando tal modelo.

Não podemos nos acostumar com a desigualdade, exclusão, fome, violência gerados pela globalização.

Ainda amparada pelos ensinamento de Pinheiro e Bassoli, ressalta-se: 
A existência humana implica em respeito às condições que lhe permitem uma sobrevivência digna. Certamente que tais condições não se resumem unicamente à questão econômica. Importa ao processo de globalização, valores que exprimem os interesses da sociedade como um todo. O meio ambiente é um dos que mais expressam a convergência de tais interesses, ainda que, por diversas oportunidades, se evidenciem antagonismos, no que diz respeito à exploração dos recursos ambientais. (2005, p.111)

A cultura da insaciabilidade, do crescimento à qualquer custo e do consumo irracional e fabricado é autofágico e precisa ser superado. Tal superação, contudo, somente poderá ser alcançada com a colaboração e integração dos Estados, pois o meio ambiente é um bem jurídico transfronteiriço, de gozo e responsabilidade de toda a comunidade humana, de interesse de Estados desenvolvidos, bem como de Estados em desenvolvimento.

Neste sentido, cidadãos e o poder público são responsáveis por aplicar políticas de conservação e aderir ao consumismo sustentável, até mesmo para que a natureza, tão essencial, não se volte contra a espécie humana.

Os compromissos internacionais já realizados precisam ser levados adiante, e novos compromissos podem ser firmados. A situação de crise ambiental que o Planeta se encontra exige ações concretas globais e locais como o maior desafio a ser enfrentado pela humanidade.

Diante desse contexto a questão que se impõe consiste em que se, diante do individualismo característico da sociedade de consumo é possível uma mudança de olhar acerca da preservação do meio ambiente. Embora muito se tenha avançado no sentido de internalização da preocupação com relação ao meio ambiente nos diversos ordenamentos jurídicos, é fundamental uma mudança nas atitudes preponderantes na sociedade contemporânea no que diz respeito às práticas consumistas.

O desafio consiste em construir um olhar conjunto sobre o meio ambiente em uma sociedade tão marcada pelo individualismo. Se por um lado os avanços tecnológicos propiciaram uma evolução em diversas áreas da vida humana, por outro, a especialização própria da tecnologia comporta grande dificuldade para se conseguir um olhar de conjunto. A fragmentação do saber realiza a sua função no momento de se obter aplicações concretas, mas frequentemente leva a perder o sentido da totalidade, das relações que existem entre as coisas, do horizonte alargado: um sentido, que se torna complexos do mundo atual, sobretudo no que diz respeito ao meio ambiente. (PAPA FRANCISCO, 2015). 
A dificuldade em construir-se um objeto comum para a sociedade contemporânea deve-se à dinâmica evolutiva das forças produtivas que ensejaram a sistematização das ciências e consequentemente a expansão de subsistemas que passaram a seguir cada um deles o telos próprio da sua racionalidade. Assim, por exemplo, o mercado passou a pautar-se unicamente pelo lucro a qualquer preço, fim último da racionalidade econômica. Nesse sentido, dispõe Clodomiro Bannwart:

"A expansão desses subsistemas aliadas à estruturação de novas formas de produção solaparam as formas tradicionais de organização, fazendo com que tais subsistemas assumissem a direção e o controle social sob a direção da racionalidade estratégica e instrumental" (BANNWART, 2012, p. 724)

Todavia, a questão ambiental somente poderá ser enfrentada de modo efetivo a partir da solidificação de uma consciência una ambiental. É preciso que os indivíduos sobreponham o interesse comum ambiental ao interesse individual do consumismo.

As evidências da degradação ambiental e suas consequências nas sociedades tornaram as fronteiras dos Estados porosas. Novos riscos decorrentes da industrialização e do novo modo de produção e consumo, ultrapassam a capacidade de ordenação dos Estados de forma singular.

Para tanto, é essencial excutir o conceito de soberania e sua flexibilização em prol de uma harmonização legislativa que garanta efetivamente a proteção e recuperação ambiental.

\section{SOBERANIA ABSOLUTA E A INCOMPATIBILIDADE COM O DESENVOLVIMENTO SUSTENTÁVEL:}

Como já mencionado, o meio ambiente foi declarado como Direito Humano fundamental na Conferência das Nações Unidas sobre o Ambiente Humano, em Estocolmo no ano de 1972. De lá pra cá, o meio ambiente tem sido pauta das discussões internacionais, passando a receber atenção especial dos Estados e organizações, figurando como tema principal de diversas legislações internas e documentos jurídicos e políticos resultantes de Fóruns, Convenções, Conferências Internacionais.

O meio ambiente encontra-se entre os Direitos Humanos de terceira dimensão, essa divisão, meramente pedagógica, têm como base os momentos históricos em que surgiram. Torna-se relevante mencionar tal divisão para demonstrar a novidade da temática no âmbito jurídico e internacional. 
Guido Fernando Silva Soares, citado por Pinheiro e Bossoli (2005, p. 123):

A proteção do meio ambiente, mediante normas jurídicas, seja nos ordenamentos internos, seja no Direito Internacional, é um assunto recentíssimo. O meio ambiente, entendido como um complexo inâmico, composto de elementos vivos e não vivos, os quais sofrem substanciais modificações pela ação do homem, passou a interessar o Direito, somente à medida que foi necessário disciplinar a ação humana e suas consequências prejudiciais à natureza e, por reflexo, à existência do próprio ser humano.

Os direitos e garantias representados na terceira geração são aqueles que remetem ao princípio da fraternidade ou solidariedade, como a paz, desenvolvimento, o meio ambiente. Têm como titular a coletividade, são os nominados direitos difusos e coletivos e tem alto teor de humanismo e universalidade, pois são voltados a todo o gênero humano e exigem não só uma atuação Estatal interna, mas ainda uma cooperação de toda a comunidade internacional para serem efetivados.

Essa inquietação comum faz surgir um novo cenário internacional. A comunidade mundial é abalada pela internacionalização dos $\mathrm{DH}$ fundamentados na dignidade humana inerente e universal.

A pessoa humana passa a figurar como valor fonte do Direito, o que acaba por impactar o tradicional conceito de soberania absoluta.

Conforme Mazzuoli (2002):

A doutrina da soberania estatal absoluta, assim, com o fim da Segunda Guerra, passa a sofrer um abalo dramático com a crescente preocupação em se efetivar os direitos humanos no plano internacional, passando a sujeitar-se às limitações decorrentes da proteção desses mesmos direitos.

A soberania deve ser encarada sob duas perspectivas: a interna e a externa.

Citando Bodin, Celso Lafer (1994), preleciona que a soberania no plano interno do território de um Estado possuí "as seguintes características: absoluta, perpétua, indivisível, inalienável, imprescritível”, é determinada pela Constituição. (p.137)

Essa soberania diz respeito ao monopólio estatal na produção das normas e aplicação do Direito, um poder que, internamente, não encontrará outro maior.

Seguindo a teoria elaborada por Hobbes, Celso Lafer cita ainda: 
A soberania, neste sentido, pode ser encarada à maneira de Hobbes como o agente público encarregado de eliminar, no território do Estado, a anarquia dos significados sobre o que é justo ou injusto prevalecente no estado de natureza. (p.137)

Sob a perspectiva externa do sistema de relações internacionais entre os Estados, a soberania absoluta seria o "estado de natureza" hobbesiano, e a "razão de Estado" de Maquiavel, ou seja, "quer dizer o não reconhecimento de uma ordem superior à qual o Estado e o seu soberano deveriam sujeitar-se na totalidade das suas manifestações.” (p.138)

As percepções de Hobbes e Maquiavel são derivadas de um realismo que se opõe a hegemonia de uma civilização à outra, a legitimação de grandes potencias como gestoras no sistema internacional, posicionando-se no sentido "da não-subordinação da soberania a qualquer outro sistema de referência que não seja ela própria.” (LAFER, 1994; p.138)

No entanto, os modelos acima serão postos de lado e outros dois serão abordados, que para os fins da presente pesquisa, são correntes ideológicas mais adequadas, já que trabalharemos com o entendimento de que "os Estados nas suas relações internacionais, encontram-se pareados, (...) em plena igualdade jurídica.” (MAZZUOLI, 2002; p.172)

A primeira, partindo de Grócio e do pensamento da interdependência e do funcionalismo, limitadores da soberania, isto porque, segundo Lafer (1994), "a sociedade internacional tem um potencial de sociabilidade e solidariedade", uma reciprocidade de interesses comuns. Um exemplo seriam as diversas formas de cooperação internacional, em que cada soberania é relativizada, transferindo parcela de si à um ente supranacional.

O outro modelo decorre das ideias de Kant, consubstanciadas na humanidade e no indivíduo como "fim em si mesmo", e nunca sendo admitido como meio. Aqui, a soberania dos Estados deve ser relativizada em prol do interesse de toda a sociedade internacional, num aspecto globalizado.

Esse pensamento segundo, proveniente de Kant, é o que melhor se amolda ao objetivo desse estudo, uma vez que, nos dias atuais, tempos de globalização, o isolamento dos Estados é algo impossível, sendo quase que obrigatória uma relação de interdependência entre eles, gerando envolvimentos transfronteiriços, multiculturais, transnacionais.

O internacionalista Valério de Oliveira Mazzuoli (2002), propõe um reestudo do preceito da soberania absoluta, "redefinindo o seu papel para a satisfação da justiça globalizada em sede de proteção internacional dos direito humanos", buscando a "existência de um novo conceito de soberania, moldado à exigências da nova ordem internacional e da proteção internacional dos direitos humanos.” (p.169) 
A nova ordem internacional, repleta de transnacionalismo e multiculturalismos, miscigenações e heterogenias de todo o tipo, "transnacionalismo não apenas dos mercados e dos agentes econômicos, mas também dos meios de comunicação, da opinião pública, das organizações não-governamentais", exige uma ruptura do paradigma da soberania tradicional absoluta. (LAFER, 1994; p.140)

Sob esse modelo contemporâneo é que surge a necessidade de se reconhecer um novo padrão de convivência internacional, onde a soberania submeta-se a ética, limite-se por um interesse maior do que o interesse interno do território dos Estados, por interesses transnacionais, globais e em prol da proteção e efetivação dos $\mathrm{DH}$, entre eles, o meio ambiente, uma vez que "não existem direitos humanos globais, internacionais e universais, sem uma soberania flexibilizadora, o que impediria a projeção desses direitos na agenda internacional.” (MAZZUOLI, 2002; p.173)

A proteção ambiental não pode existir sem a flexibilização das soberanias dos Estados no sentido de se criar legislações mais harmônicas, colaboração e integração.

Nessa perspectiva ensina Edis Milaré:

Não há como desconhecer as ingentes dificuldades que amarram, de mil maneiras, a implantação legal de uma ordem internacional para o meio ambiente. Além dos inúmeros conflitos de interesse nas esferas pública e privada- que por si só explicam os impasses que fecham o caminho a governos, as organizações da sociedades civil e a grupo de cidadãos comprometidos com a qualidade ambiental-, o estatuto da soberania dos Estados-nação constitui-se em grande empecilho a uma legislação de caráter inter ou supranacional para a defesa do meio ambiente, em âmbito planetário e em outros âmbitos menores, até mesmo nas relações bilaterais. (2005, p. 1049)

Se faz necessário o fortalecimento do Direito Público internacional, que através de agentes supranacionais criem regras e limites que garantam o meio ambiente ecologicamente equilibrado e sadio, ao contrário será o mercado o responsável por fazer suas próprias regras, deixando a preservação ambiental sempre à margem dos interesses econômicos capitalistas.

A globalização da economia provoca um vazio de Direito Público Internacional idôneo que possa regular o poder econômico.

Assim sendo, para que se faça possível a superação de tal lacuna, eliminando as disparidades extremas existentes entre os Estados e a proteção e recuperação do meio ambiente se torne efetiva, é indispensável que sejam fortalecidas as instituições internacionais 
públicas e que os Estados flexibilizem sua soberania na ordem internacional, alargando suas perspectivas para além dos interesses nacionais, no sentido de um global governance.

Tal medida já possui fundamento em vários documentos internacionais, como por exemplo, a Carta da Terra que traz de maneira expressa:

A escolha é nossa: formar uma aliança global para cuidar da Terra e uns dos outros, ou arriscar a nossa destruição e a da diversidade da vida. São necessárias mudanças fundamentais dos nossos valores, instituições e modos de vida. [...] O surgimento de uma sociedade civil global está criando novas oportunidades para construir um mundo democrático e humano.

Nossos desafios ambientais, econômicos, políticos, sociais e espirituais estão interligados, e juntos podemos forjar soluções includentes.

No atual mundo globalizado, conservar o clássico conceito de soberania absoluta implica em hostilidade a ideia de responsabilidade partilhada que permita a proteção efetiva à integridade do meio ambiente. Como bem ensina Klaus Bosselmann (2015, p.184), "esse ponto de vista define o 'Estado' em oposição direta ao meio ambiente global. O Estado-nação representa a fragmentação, o ambiental representa unidade."

A lógica da integridade ecológica exige uma governança global, onde não haja Estados soberanos entre si, e onde a soberania interna seja limitada em prol de uma ambiente planetário limpo e sadio.

Ainda segundo Bosselmann, "o argumento para uma redefinição da soberania territorial” está no fato "que os territórios nacionais são parte do ambiente global e, portanto, limitados em seu uso e exploração". (2015, p. 188)

Tentando apresentar um solução para a tensão havida, Bosselmann considera dois fatores: primeiramente, um problema conceitual e um segundo fator, que chama de mudança de identidade.

No primeiro explana que, o meio ambiente, indivisível que é, é incompatível e contrário à fragmentação da legislação ambiental entre os países. "enquanto o pensamento ambiental foca no ambiente global, o pensamento jurídico foca no Estado.

No nível interno os Estados produzem leis ambientais segmentadas, que ignoram a integridade do ambiente, internacionalmente, com fulcro na soberania absoluta, permitem aos Estados escolher se cumprirão ou não as normas ambientais estabelecidas, o que fragmenta e enfraquece a legislação ambiental. 
Quanto a mudança de identidade, o autor traz a ideia de que o conceito de soberania não é estático, sofrendo constantes mudanças à medida que os Estados se deparam com novas circunstâncias, como ocorreu com a globalização econômica e abertura dos mercados.

Para Bosselmann, "a globalização da economia e ecologia é o maior desafio do Estado soberano desde a sua criação através do Tratado de Vestefália de 1648. Na era da globalização, o estado territorial moderno está claramente em busca de uma nova identidade." (2015, p. 189)

O conceito jurídico de soberania deve corresponder à realidade, que está em processo de mudança. A soberania nacional "está em desacordo com a indivisibilidade do meio ambiente global, a única opção que resta é reajustar a ficção legal à realidade ecológica". (BOSSELMANN; 2015, p.189)

Diante desse cenário de sociedade globalizada e interligada, o Estado nacional perde forças, uma vez que as mazelas do mundo contemporâneo, dentre as quais, a degradação e má utilização ambiental, transpassam as fronteiras territoriais, fugindo ao controle e jurisdição dos Estados, culminando na Crise do Estado.

Para transpor tais obstáculos, a doutrina apresenta várias propostas, nesse estudo compactuamos com a ideia de flexibilização da soberania e fortalecimento e/ou criação de organismos e instituições supranacionais de caráter público, com poder para criar obrigações, cobrar responsabilidades dos Estados, para assim garantir os direitos já consagrados e reconhecidos como fundamentais e universais, entre eles, o meio ambiente sadio.

Segundo Bosselmann (2015, p.189-190), “o conceito de Estado soberano é dinâmico, ele também está aberto a novas funções e responsabilidades, desde que suas funções básicas de governar e servir os interesses comuns não esteja em risco. [...] Da perspectiva da sustentabilidade, os interesses comuns sugerem limitações à soberania do Estado que permitam alguma forma de governança global".

O interesse comum na preservação do ambiente global é uma das principais características do direito ambiental internacional, contudo, a soberania territorial dos Estados afasta a ficção jurídica da realidade ecológica.

Analisemos como exemplo a questão da preservação e proteção da água.

A água é um recurso ambiental essencial na criação e manutenção da vida animal e vegetal. É de suma importância para o desenvolvimento de atividades econômicas das mais variadas, como agricultura, geração de energia elétrica, navegação, indústria etc. Na história da humanidade, esse líquido teve papel fundamental na formação e no progresso das civilizações, desde as mais primitivas às avançadas. 
A Conferência das Nações Unidas sobre o Ambiente Humano, em 1972, adotou a proteção das águas como o mais indispensável dos recursos naturais. Esse entendimento passou a receber atenção especial dos Estados e organizações internacionais, figurando como tema principal de diversas legislações internas, documentos jurídicos e políticos resultantes de fóruns, convenções, conferências internacionais sobre água.

Em 2010, a Organização das Nações Unidas (ONU) declarou a água um direito humano essencial ao pleno gozo da vida e de todos os demais direitos humanos, sendo inerente à todo indivíduo.

No entanto, o conceito clássico de soberania nos remete a ideia de que os Estados são soberanos para explorar os recursos naturais presentes em seus territórios, sem qualquer interferência externa. Tal posicionamento leva a exploração indiscriminada de tal recurso, em termos quantitativos e qualitativos, sem qualquer responsabilidade ou compromissos dos Estados nacionais com a comunidade global.

Se considerarmos o Brasil, por exemplo, o Estado detém, segundo a Food and Agriculture Organization of the United Nations (FAO), aproximadamente 12\% de toda a água doce superficial do planeta. De acordo com pesquisas realizadas pelo Programa das Nações Unidas para o Desenvolvimento (PNUD) apontam para o desperdício mundial anual de aproximadamente $1.500 \mathrm{~km}^{3}$ de água, sendo, conforme o relatório para o Fórum de Águas das Américas, preparado pelo Banco Interamericano de Desenvolvimento, o desperdício médio nacional no Brasil é superior à $50 \%$.

Dados como esses colocam o Estado brasileiro em papel de destaque na preocupação mundial no que se refere ao uso e proteção da água, uma vez que essa, sendo reconhecida como Direito Humano, pertence à toda a espécie, um interesse comum da humanidade.

Tal cenário é totalmente inaceitável e insustentável, mas se perpetua, uma vez que o Estado brasileiro, é no termo clássico, soberano para explorar a água presente em seu território, desprezando qualquer compromisso planetário. Evidente irresponsabilidade e descuido está no desastre ambiental ocorrido na cidade de Mariana-MG, em dezembro de 2015, atingindo o Rio Doce, atravessando estados até desembocar no mar, espalhando-se por quilômetros, destruindo fauna, flora e contaminando recursos hídricos sem qualquer punição ou cobrança de medidas reparatórias.

De certo que se trata de um evento ocorrido em território nacional, mas as consequências de tamanha tragédia serão suportadas por toda a coletividade humana e não humana. 
O conceito de soberania territorial surge para proteger as fronteiras dos Estados, a utilização de seus territórios e recursos. A soberania absoluta dos Estados sobre seus territórios se assemelha a do particular em relação à sua propriedade no século XIX.

É explicito o caráter de interesses econômicos por trás desse entendimento e desse último, na elaboração das legislações internas e de documentos internacionais elaborados com a proposta de proteção do meio ambiente.

O Princípio 21 da Declaração de Estocolmo deixa patente esse juízo:

\section{Princípio 21}

Em conformidade com a Carta das Nações Unidas e com os princípios de direito internacional, os Estados têm o direito soberano de explorar seus próprios recursos em aplicação de sua própria política ambiental e a obrigação de assegurar-se de que as atividades que se levem a cabo, dentro de sua jurisdição, ou sob seu controle, não prejudiquem o meio ambiente de outros Estados, ou de zonas situadas fora de toda a jurisdição nacional. (Declaração da Conferência de ONU no Ambiente Humano, p. 6)

Em termos de obrigações reais, a postura adotada no Princípio 21, fragmenta a proteção do ambiente e ainda se coloca como mera recomendação aos Estados para que, regulamentem, por meio de suas legislações internas, a exploração dos recursos naturais pelas atividades econômicas dentro de suas fronteiras e que "cuidem" para que essas atividades não gerem danos para além de suas divisão territorial.

Há quase uma mensagem subliminar autorizando a exploração excessiva e a degradação ambiental sem responsabilidade, desde que ela se restrinja aos limites territoriais de cada Estado e em relação à possíveis danos ambientais transfronteiriços, uma solicitação de cooperação para evita-los.

A atual dinâmica, centrada no Estado, traz graves consequências à efetiva preservação ambiental. Ter a soberania territorial como absoluta leva à uma dominação das necessidades humanas sobre as necessidades ecológicas, o predomínio de interesses econômicos sobre os interesses comuns de uma sociedade globalizada.

Bosselmann, propõe uma conciliação entre soberania territorial e a sustentabilidade ambiental.

O autor ensina que uma governança sustentável e global oferece uma perspectiva mais ampla do que à apresentada pela governança tradicional com centro no Estado. 
Em uma governança sustentável e global, o ambiente externo é internalizado, integrando o meio ambiente nacional como "algo mais ampla, transnacional ou global". (BOSSELMANN; 2015, p. 203)

A proposta de se limitar a soberania territorial busca, como indica o autor, "quebrar o monopólio do Estado soberano em definir o escopo e o alcance das estratégias ambientais", defende-se a ideia de um ambiente comum como foco referencial para obrigações ambientais.

Não se trata de abolir a soberania territorial dos Estados, mas sim reformulá-la. O que se deseja é uma transferência de parte da soberania dos Estados à um patamar supranacional, em especial no que se refere à direitos humanos e o direito à um meio ambiente equilibrado.

A soberania territorial, diante desses direitos, estaria restrita e/ou limitada, a perspectiva passa de centralizada no Estado para uma nova agenda global. "Em termos estratégicos, as funções de soberania do Estado são relativas às necessidades da sociedade civil. Em termos políticos, os Estados não devem abrir mão da soberania à realidades globais.” (BOSSELMANN; 2015, p. 208)

Assim como a propriedade privada deixa de ser absoluta, abrindo espaço para a redefinição, numa dimensão social (função social da propriedade), a soberania territorial não pode se conservar absoluta diante de um mundo globalizado. A soberania do Estado exige uma transformação em sua dimensão internacional, protegendo a comunidade planetária de guerras, terrorismo e no caso em tela, da destruição ambiental.

A soberania limitada não elimina o direito dos Estados em usar os recursos naturais de seus territórios, mas o proíbe de abusar, degradar, poluir, desperdiçar e omitir-se, irresponsavelmente, diante de tais condutas quando praticadas por agentes econômicos de quaisquer espécie. O objeto paradigma para se discernir o que é uso (amparado pela soberania), do que é abuso (uso excessivo e degradação), é a própria sustentabilidade ambiental.

Dessa forma, o princípio da sustentabilidade é indispensável para a transformação e flexibilização da soberania, para a presente pesquisa, essencial na efetivação da preservação e proteção do meio ambiente global.

INSUSTENTABILIDADE DOS ECOSSISTEMAS E OS OBJETIVOS DE DESENVOLVIMENTO SUSTENTÁVEL: 
Com o mercado capitalista e com as inovações tecnológicas, o meio ambiente passou a ser cada vez mais explorado e sobrepujado. De uma relação de subsistência, o ambiente passou, progressivamente, ao domínio humano.

Neste contexto o Estado precisou intervir nas questões relacionadas à degradação ambiental. Surge, assim, um novo padrão normativo, voltado a proporcionar a preservação do meio ambiente através, principalmente, da utilização racional dos recursos naturais planeta. Essas novas funções atribuídas ao Estado fazem-no adquirir as características do Estado de Direito Ambiental, assim definido por AYALA e LEITE (2011, p. 39-40):

O Estado de Direito Ambiental constitui um conceito de cunho teórico-abstrato que abrange elementos jurídicos, sociais e políticos na persecução de uma condição ambiental capaz de favorecer a harmonia entre os ecossistemas e, consequentemente, garantir a plena satisfação da dignidade para além do ser humano.

... O Estado de Direito Ambiental é uma construção abstrata que se projeta no mundo real apenas como devir.

Há, portanto, uma com forte atuação no ordenamento jurídico, que deverá voltar-se para a efetivação desse novo Estado, viabilizando-o e garantindo-o através, especialmente, de uma tutela jurisdicional ambiental célere e diligente.

De fato, a crítica dirigida ao modelo de desenvolvimento com exploração inadequada dos recursos naturais recai sobre o acirramento das injustiças sociais e o esfacelamento cultural nativo. Ao abordar o assunto Ignacy Sachs afirma a necessidade da realização do ecodesenvolvimento, baseado no reconhecimento e proteção de peculiaridades culturais, ecológicas e econômicas, e fomentando a adoção de medidas baseadas nestas peculiaridades para a promoção do desenvolvimento socioambiental. Não se trata de negar o valor de experiências alheias, mas de refutar "soluções pretensamente universalistas e fórmulas generalizadas" (SACHS, 2008, 54.).

Embora haja estudos que demonstrem a conceito Sustentabilidade com existência a mais de 400 anos, o ponto de partida do presente trabalho será a Sustentabilidade em seu atual sentido, que emerge a partir do final do século XX, com a Comissão Mundial sobre Meio Ambiente e Desenvolvimento (CMMAD), criada pelas Nações Unidas em 1983 e que culminou na elaboração do documento "Nosso Futuro Comum", conhecido por Relatório de Brundtland.

Nesse Relatório temos o "Desenvolvimento Sustentável” como: "aquele que atende às necessidades das gerações atuais sem comprometer a capacidade das gerações futuras de 
atenderem às suas necessidades e aspirações". Para Leonardo Boff (2012, p.34), tal "definição se tornou clássica e se impôs em quase toda literatura a respeito do tema".

Contudo, Boff atribui a esse conceito de Sustentabilidade, pelo menos duas limitações: "é antropocêntrico (só considera o ser humano) e não menciona a comunidade de vida (os demais seres vivos da biosfera)".

A partir desse debate é possível considerar que o conceito de Sustentabilidade apresentado pelo Relatório de Brundtland, não mais atende as necessidades da sociedade contemporânea.

Ao caminharmos um pouco mais na história, chegamos ao conceito sugerido pela Conferência das Nações Unidas sobre Meio Ambiente e o Desenvolvimento (CNUMAD), também conhecida como Rio- 92 ou Cúpula da Terra, que apresentou a Sustentabilidades como uma construção histórica, social, política, econômica, ambiental, colocando o "Desenvolvimento Sustentável" no centro da tríade Social- Econômico- Preservação Ambiental.

Esse modo de conceber a Sustentabilidade, assim como primeiro, tornou-se largamente aceito pela doutrina e legislações nacionais.

Todavia, em consequência às frequentes flexibilizações de leis, políticas públicas para atender à interesses econômicos e políticos, tal entendimento acabou encarado como definição fraca, desconstituído de efetividade, fazendo surgir um conceito abstrato que atua como "maquiagem verde" a ser explorado comercialmente.

Parte-se então para a uma ressignificação da Sustentabilidade como um novo valor, em construção constante, que almeja efetividade em sua aplicabilidade, garantido um meio ambiente sadio e equilibrado, não só para a geração presente, mas para geração vindoura, na melhor aplicação do princípio da solidariedade e da fraternidade.

Um conceito de Sustentabilidade que atenda as demandas da sociedade atual, deve pautar-se não somente na tríade Social- Economia- Ambiental, mas considerar ainda as dimensões apresentadas pelo autor Juarez Freitas (2012): dimensão jurídico- política, pois trata-se de princípio gerador de novos direitos e obrigações e a dimensão ética, já que para enfrentar os desafios ambientais e tornar o mundo habitável, é preciso considerar o ônus de nosso próprio comportamento ao longo da história e o compromisso existente com as gerações presentes e futuras. Importante mencionar, para o filósofo e professor Mario Sérgio Cortella (2014), “a crise ecológica vivida nos dias de hoje, é uma crise ética”. 
Não podemos nos acostumar com a desigualdade, exclusão, fome, violência gerados pelo sistema que adotamos e pela sociedade de consumo em que vivemos.

A Sustentabilidade é indissociável de um ideal de bem viver, mas esse bem viver é coletivo! Na sociedade atual o conceito que se busca é o de um "Desenvolvimento Sustentável", no seu sentido mais amplo e completo.

Na esfera internacional, no ano de 1992, na famosa Cúpula da Terra, foi traçado o primeiro esboço da Agenda 21, que buscava estabelecer um plano de ação para o século XXI. Ao lado da Agenda 21, são criados os Objetivos de Desenvolvimento do Milênio (ODMs), instrumentos umbilicalmente ligados na consecução do "Desenvolvimento Sustentável”.

Dentre os 8 ODMs, destaca-se: "a melhoria das condições de vida da população global; combate à pobreza extrema; erradicação da fome; etc”, os ODMs obtiveram ao longo desses anos, muitos resultados positivos, mas ainda assim não conseguiu diminuir as desigualdades de renda no mundo. Tal desigualdade está intimamente vinculada as questões ambientais e padrões de produção e consumo, ocupação do solo e uso da terra.

Essa desigualdade social que não pode ser estancada na aplicação dos ODMs, está sendo colocada em pauta recente na construção de um novo plano de ação traçado pelas Nações na comunidade internacional, naquilo que vem sendo nominado "Agenda pós-2015" ou ainda "Agenda 2030 para o Desenvolvimento Sustentável”, que traz 17 novos objetivos a serem perseguidos, os Objetivos de Desenvolvimento Sustentável (ODSs).

Tal documento não se reduz a meras recomendações, mas trazem metas (169 no total) sobre meios de implementação, acompanhamento e revisão de instrumentos que possam auxiliar efetivamente no alcance dos novos objetivos traçados.

Neste sentido, há algumas décadas vem sendo construído um conceito de desenvolvimento sustentável em relação ao meio ambiente, cujos contornos vêm sendo (ou deveriam ser) os parâmetros para as atividades públicas e privadas daqueles países que o tem como princípio. Mesmo sendo um conceito aberto, sujeito a múltiplas apropriações, é possível, pois, definir o Desenvolvimento Sustentável como sendo: “um modelo econômico, político, social, cultural e ambiental equilibrado, que satisfaça as necessidades das gerações atuais, sem comprometer a capacidade das gerações futuras de satisfazer suas próprias necessidades". (LAYRARGUES, 1997, p. 1-5)

A propositura dessa nova Agenda e Objetivos apresentados pela Organização das Nações Unidas, trará mais um impacto ao conceito de Sustentabilidade, pois insere-se a 
contenda um ideal de Justiça Social e Ambiental, essencial ao pleno desenvolvimento dos povos e da humanidade global.

\section{CONSIDERAÇÕES FINAIS}

O desenvolvimento social e econômico experimentados ao longo dos últimos séculos aliado aos novos modos de produção vêm consumindo cada vez mais os recursos naturais a ponto de levar a escassez dos mesmos. Urge uma nova forma de ver e agir em prol do meio ambiente e seus elementos, de um olhar solidário com nosso planeta e a natureza.

Contudo, a proteção ambiental global, vai de encontro, no que tange a sua real efetivação, ao conceito de soberania absoluta dos Estados, ainda fortemente defendida e preservada.

Em virtude de tal posicionamento, temos o enfraquecimento do Direito Ambiental Internacional, pois temos um ambiente considerado de forma fragmentada, a ausência de agentes e instituições públicas supranacionais fortes o suficiente para "cobrar" do Estados a conduta assumida internacionalmente e aa responsabilidades dela decorrentes.

Também foi possível perceber que o Direito Ambiental Internacional, prevê direitos, mas não possui meios de garantia eficientes ao pleno exercício do direito ao meio ambiente limpo e sadio para toda a comunidade humana.

Que para a efetivação do pleno exercício a tal direito, exige-se a transformação do conceito de soberania, que transcenda as fronteiras e interesses de cada Estado em prol de um interesse maior, o interesse comum de manutenção da vida, não só de comunidades determinadas, mas de toda a humanidade.

Para tanto, não se faz necessário e nem se propõe a extinção da soberania estatal, mas sim sua flexibilização, com o fortalecimento ou criação de instituições supranacionais de caráter público, com meios eficazes de coação e de responsabilidade partilhada dos Estados, não só em face à condutas incompatíveis aos interesses da comunidade global, mas pela própria manutenção por um ambiente limpo e sadio.

Enfim, a construção de um novo conceito de soberania, onde prevaleçam os interesses da humanidade, em busca de uma global governance.

A globalização alterou a geografia do mundo, nos fez transpor fronteiras territoriais e viver integrados, interligados. Com o meio ambiente temos tal interdependência ainda mais evidente, por suas características peculiares, estamos "todos no mesmo barco". 
Assim, a integração e a cooperação entre países soberanos para proteção do ambiente global, traduz a melhor forma de gestão para sustentabilidade ambiental.

Ações isoladas e legislações internas, fragmentadas, embora tenham sua importância na proteção e preservação ambiental, são insuficientes e ineficazes quando falamos em meio ambiente global. É preciso deixar as fronteiras de nossos Estados, abandonar nossas nacionalidades em prol de um planeta sadio e equilibrado para toda a comunidade global.

\section{REFERÊNCIAS BIBLIOGRÁFICAS}

ANTUNES, Paulo de Bessa. Direito ambiental. Rio de Janeiro: Lúmen Júris, 2008.

BARBIERI, José Carlos; CAJAZEIRA, Jorge Emanuel Reis. Responsabilidade social empresarial e empresa sustentável: da teoria à prática. São Paulo: Saraiva, 2009.

BOFF, Leonardo. Sustentabilidade: o que é, o que não é. Petrópolis: Vozes, 2012.

BOSSELMANN, Klaus. O princípio da sustentabilidade: transformando direito e governança. trad. Phillip Gil França. São Paulo: Revista dos Tribunais, 2015.

BRASIL. Constituição (1988). Constituição da República Federativa do Brasil. Brasília, DF: Senado Federal: Centro Gráfico, 1988.

CARTA DATERRA. Disponível:

<http://www.mma.gov.br/estruturas/agenda21/_arquivos/carta_terra.pdf>. Acesso em: 23 jan. 2016.

CORTELLA, Mario Sérgio. Qual é a tua obra?: inquietações propositivas sobre gestão, liderança e ética, 23 ed. Petrópolis: Vozes, 2014.

DECLARAÇÃO DE ESTOCOLMO. Disponível: <http://www.apambiente.pt/_zdata/Politicas/DesenvolvimentoSustentavel/1972_Declaracao_ Estocolmo.pdf>. Acesso em: 23 jan. 2016.

DIAMOND, Jared. Colapso: como as sociedades escolhem o fracasso ou o sucesso. Rio de Janeiro: Record, 2005.

FREITAS, Juarez. Sustentabilidade: direito ao futuro, 2ªed. Belo Horizonte: Fórum, 2012.

FREITAS, Juarez. Sustentabilidade: direito ao futuro, 2ªed. Belo Horizonte: Fórum, 2012.

HABERMAS, Jurgen. A constelação pós-nacional: ensaios políticos. trad. Márcio Seligmann Silva. São Paulo: Litera Mundi, 2001. p. 75- 141.

LAFER, Celso. A Soberania e os Direitos Humanos. Texto apresentado no painel "Ética nas Relações Internacionais", XV Conferência Nacional da OAB, 1994. Disponível: 
<http://www.scielo.br/pdf/ln/n35/a06n35.pdf>. Acesso em: 23 fev. 2012.

LOBATO, Francisco. FORO DEL AGUA DE LAS AMÉRICAS: Informe de la subregión sudamérica. Banco Interamericano de Desarrollo. 2008. Disponível: <http://www2.ana.gov.br/site/arc/>. Acesso em: 13 abril 2014.

MAZZUOLI, Valério de Oliveira. Soberania e a proteção internacional dos direitos humanos: dois fundamentos irreconciliáveis. Brasília: Revista de Informação Legislativa, dez. 2002. Disponível:

<http://www.stf.jus.br/repositorio/cms/portalTvJustica/portalTvJusticaNoticia/anexo/Artigo Soberania_e_Direitos_Humanos_Valerio_Mazzuoli.pdf>. Acesso em: 14 dez. 2011.

MILARÉ, Édis. Direito do Ambiente. São Paulo: Revista dos Tribunais. 2005.

MINDLIN, Sérgio. ONU proclama 20 de março como Dia Internacional da Felicidade. Disponível em: <http://www3.ethos.org.br/cedoc/onu-proclama-20-de-marco-como-diainternacional-da-felicidade/\#.VliFEXIZmXs>. Acesso em: 07 dez. 2014.

PINHEIRO, Ana Cláudia Duarte; BASSOLI, Marlene Kempfer. Sustentabilidade econômica e ambiental: um ideal da sociedade internacional. Revista Scientia Iuris, v. 9. Londrina, 2005. p. 109- 130. Disponível: < http://www.uel.br/revistas/uel/index.php/iuris/article/view/4044>. Acesso em: 23 de jan. 2016.

VEIGA, José Eli da. Sustentabilidade: a legitimação de um novo valor. São Paulo: SENAC São Paulo, 2010. 